\title{
18. Observing the Present: Writing the Past
}

Pacific Lives, Pacific Places: Bursting Boundaries in Pacific History, edited by Brij V. Lal and Peter Hempenstall, pp. 22-33. Canberra: Journal of Pacific History.

On Monday 27 March 2000 I landed at Jacksons Airport, Port Moresby. I shuffled off Qantas flight QF95 through the covered tunnel, into the new air-conditioned airport, and went by air-conditioned car to the Airways Hotel with its grand entrance, polished wood floors, silent lift and blocks of air-conditioned rooms clinging to the slope.

It was almost exactly thirty-four years since I had first landed at Jacksons. I had then flown all night on the TAA Bird of Paradise Electra ('Big. Powerful. Fast. Smooth. Slice two hours from the Territory/Australia trip'), arrived just after dawn, walked across the tarmac through air so dense it was like wading through a cappuccino, presented my entry permit to the Australian official, waited in the open-sided shed that catered for all passengers from Kieta or Lae or Sydney, and went by car, windows down, shirt sticking to the seat, past Four Mile and down the dusty, gravel road to the isolated Administrative College housing in Waigani.

The change in the speed and ease of travel, and the fact that it is possible now to move within a protective cocoon, is significant. But other changes are obviously more important. TAA (The Friendly Way) was an Australian domestic airline. In 1966 the customs officers and airport officials were all Australians. Banks were branches of Australian banks - the Commonwealth, the Bank of New South Wales - the currency was Australian, and the tellers and the customers were all Australians - except perhaps for a nervous group of Papua New Guineans waiting for the most literate among them to join the queue, and wait for a turn to enter the alien world of commerce. In 1966 all members of the First Division of the Public Service were white, and in the Second Division (where the minimum entry was three years of secondary schooling) Papua New Guineans were outnumbered twenty to one. The senior police were all white, but in 1964 the first two Papua Guineans were appointed as sub-inspectors, so the old barrier that had stopped Papua New Guineans rising above the ranks of sergeant and warrant officer had ended. Even so, a newly arrived Australian going into the Port Moresby police station to change a State to a Territory driving licence was more likely to be served by a white woman office worker than a Papua New Guinean policeman. The 'Pacific Islands Regiment' was a unit of the Australian Army, controlled by the Australian Defence Act, and over 600 of the 3000 personnel were white. 
All senior officers and technical staff were Australian. As in the police the first officers had recently been appointed: Second Lieutenants Ted Diro and Patterson Lowa had been commissioned in 1963.

At the top of Hunter Street, the House of Assembly, the archives and the museum shared the modest building that had once been the European hospital. In the Assembly the debates, both for and against, were dominated by Europeans. The radio station, 9PA, was run by the $\mathrm{ABC}$, and most of its announcers had careers that considered a shift to Port Moresby as not much different from one to Launceston or Townsville. The news services in Motu and Pidgin and the broadcasts to schools presented by Papua New Guineans did at least give the $\mathrm{ABC}$ a local distinction to balance its familiar Australian accents and 'Blue Hills', with its evocation of a past Australia. The daily newspaper, the South Pacific Post, had just come under the control of the Herald and Weekly Times of Melbourne and was later to become part of the growing empire of Rupert Murdoch. It was written by and for Australians, the advertisements were directed at the Australians, the sporting teams most reported were dominated by Australians and a few were exclusively white.

In 1966 an Australian travelled in an Australian Territory and was carried, directed, serviced, protected, punished and entertained by Australian institutions. It was not even clear if or when Papua New Guinea was going to end its constitutional association with Australia. The Minister, Charles Barnes, had been to Port Moresby in January and declared that when the time came, the people of Papua and New Guinea could choose for themselves what they wanted. In February Pacific Islands Monthly said that if the 'majority of Papua-New Guinea's moderate, not very ambitious leaders then had to choose they would opt for close ties with Australia'. But among general uncertainty it did seem that Mr Barnes had made it clear that there was no chance of the Territory becoming a seventh state of Australia. A report, just made public, reminded Australians that there were still parts of the Territory where government, exploration and adventure were one. Assistant District Officer R.I. Barclay and Cadet Patrol Officer K. Taylor had walked for eighty days through the headwaters of the April and Leonard Schultz Rivers where they were the first government officers to contact several hundred people. Simply the appearance of the people with their bark topknots and cane waistbands - not their aspirations for statehood -was news. Barclay, Taylor, five policemen and over fifty carriers had crossed a river fortytwo times in one day and gone without food for four days as they penetrated the deep gorges at the divide between the Sepik and Western Districts to meet timid, suspicious peoples. The Territory was still an Australian frontier, and the land recently described by McCarthy and Souter (and about to be described by 
Sinclair) was still out there. In 1966 Australians were discovering Papua New Guinea as they were trying to change it more rapidly than ever before, but the extent to which they were preparing for complete separation was unclear.

When I arrived at Jacksons airport in 2000 I joined the queue for foreigners entering the country. I presented my Australian passport and visa which allowed me a single entry, prohibited work and required me to have a return ticket. It was checked by a Papua New Guinean immigration officer and my luggage was inspected by Papua New Guinean customs officers. A young Papuan woman asked me, 'Have you been to our country before?' I thought about explaining that I had been many times before, and that the first time I came it was my country, but that at some time it had become hers. The formal date of transfer was 16 September 1975, but in fact over time I had observed the country going from 'ours' to 'theirs'. Perhaps I should have said that the country had always been hers, but when I first came to Papua New Guinea Australian institutions had been imposed across the surface of a small part of the country and this had made it possible to travel from Brisbane to Boroko within a familiar Australianness. I simply said, 'Yes'.

Historians write from a particular present. For historians of Papua New Guinea that present has changed radically. The visible changes are most obvious to me as I drive through the suburb of Boroko - from the Hubert Murray Highway, down Boroko Drive and then back along Vaivai Avenue. In 1966 Port Moresby had a population of just over 40,000 and 10,000 were expatriates. About one third of the expatriates lived in Boroko. All those louvre-windowed bungalows, on high concrete posts, all those cars parked underneath and in the driveways, all those neat Sogeri grass lawns, all the bauhimia, allamanda, ixora, bougainvillea, hibiscus, tanket and travellers' palms bought from Sheedy's at Six Mile, all the blue-lined Clark swimming pools, all were possessed by Australians and reflected Australian aspirations for the good suburban life. The Papua New Guineans who washed, cooked, cleaned and gardened in many of the Boroko houses were scarcely visible, although they numbered just a few less than the Australians.

In 2000 Port Moresby has a population of about 400,000 and in that city ten times greater what were once called 'expats' and now 'non-citizens' are fewer, and the Australians are the tiny minority - perhaps 3000. In Port Moresby less than one in a hundred is an Australian. Boroko and Korobosea, so obviously white suburbia in 1966, are now home to over 25,000 Papua New Guineans.

Suburbs in other cities change their ethnicity. Parts of New York went from being Irish to East and Southern European to African-American. Richmond in Melbourne changed from Tigerland to Little Saigon. But what happened in Boroko is more significant. The Australians have not moved to another more 
spacious, leafier suburb with higher real estate values and lower crime rates - they have gone altogether. Boroko was the leafy suburb. It did not compete with Airvos Avenue and other streets on Touaguba with their views of the harbour or reef and Coral Sea; but it was a suburb of privilege and power. This has been a shift of people in terms of power as well as a shift in space, and it has been almost complete.

The change in the present is also apparent in the extent to which people feel at ease. Questions of 'law and order' constantly intrude on all peoples' daily activities; much ordinary activity is curtailed or conducted at risk. Crimes of outrageous bravado capture headlines. On 17 December 1999 a gang hijacked a helicopter and tried to rob the Port Moresby headquarters of the Papua New Guinea Banking Corporation. Intercepted by the police, four were shot dead and a fifth died on the way to hospital. Using a Toyota Landcruiser stolen in Lae, five men drove into Lalibu in the Southern Highlands, held up the bank, and left with K22,000. In November 2000 hijackers armed with rifles and hand grenades ordered a light aircraft on a regular run between the Morobe goldfields and Lae to divert to Graraina. There they unloaded $\$ 262,000$ worth of gold and disappeared into the bush. Equally audacious, but more profitable and less dangerous, have been the misappropriation of funds. The assets of the Motor Vehicle Insurance Trust, Post PNG, the National Provident Fund, and the Investment Corporation of PNG had, the Prime Minister Sir Mekere Morauta said, been 'raped and plundered'. The Motor Vehicle Insurance Trust had shrunk from a value of K150 million to K3.89 million. Monies have moved through accounts in Australia, Hong Kong, Switzerland and the Cayman Islands and individuals have - sometimes deviously but legally - rewarded themselves with payments in the millions. People die in acts of careless and wanton violence. A six-year-old girl was shot dead while travelling with her parents on the Magi Highway just outside Port Moresby. An Enga man in the suburb of Morata was blown to pieces by a hand grenade and in revenge three men were chopped to death. In March 2000, I was parked outside the National Archives, just off Independence Drive. The archives close at lunchtime, and as I waited a few minutes for the reading room to reopen I sat in my car reading the Post-Courier. A member of staff immediately came out and told me to come inside and wait. To sit in a car with the door open, I was told, was to invite someone to steal it, and I might be injured in the process.

When I returned to the Archives and began reading the District Commissioners' Annual Reports the present dominated. I could not stop thinking about the questions of law and order; they arise from immediate conversations, and from ordinary and extraordinary events. Were the crimes related to particular values and ways of behaving in Melanesian cultures? What had happened to those opposing forces in Melanesian cultures, those that restrained the hot heads and 
ensured peace and harmony? To what extent had Australian institutions been inefficient or inappropriate? Why had the values proclaimed by governments and missions had so little apparent impact? What was the relationship between the resurgent tribal fighting, armed robbery and fraud and corruption? Where should Papua New Guinea government and foreign aid agencies direct their aid to obtain immediate and long-term benefits? How should we interpret those post-war years of apparent peace, low levels of crime, and the dominance of Australians and Australian institutions? Were these superficial and ephemeral impositions, coming under increasing strain even before the Australians handed over power?

The District Commissioner for Kieta District reported in 1948 from Sohano that as a result of recent patrolling the estimated decline in population on Bougainville during the Second World War was between twenty and twenty-five per cent. Losses had been heaviest in the Kieta and Buin areas. Patrol officers listed the losses from the direct and indirect results of war people shot for presumed aid to the enemy, killed by strafing aircraft, deaths from deprivation, and from other New Guineans who took advantage of the turmoil of war to attack old enemies. Particular cases were referred to Crown Law Officers to see whether war damage compensation should be paid. Korovei, a man aged about twenty-two from the Reboine area south of Kieta, had taken refuge with the inland Nasioi when air strikes increased against the Japanese occupying his village. He had died of exposure and malnutrition. Onaba Bora of Keveri was in Abau in 1944 to give evidence in a court case. Two Americans asked him to provide a woman who would have sexual intercourse with them. Onaba refused and they bashed him with pistol butts, leaving him paralysed. He got around the village in a sitting position, lifting himself with his hands. Both cases merited compensation.

When I first read post-war patrol reports, I had sat in a room at Konedobu at the headquarters of DDA - the Department of District Administration, at the very source of Australian imposed peace. From that place at that time, the violence of war seemed a terrible aberration: the violence of a world war had fallen on a people who had both accepted and appreciated peace. In 2000 I was entering the Archives to escape a dangerous world. It was then possible to see some parts of Papua New Guinea as being engaged in persistent tribal warfare, the Australian rule having been imposed with force and the threat of force, the war suddenly introducing vastly greater and less predictable violence, and by the early 1970s these areas were again places where armed men solved disputes and redistributed wealth. In March 2000 peace could be seen as an aberration. Of course the present influences all historians, but in one generation in Papua New Guinea the transformation has been so great in where people live, who 
they are, what wealth and power they have, and how they behave, that the questions historians might ask and the answers they suggest have taken an equally sharp turn.

Soon after first arriving in Papua New Guinea I began to write about it. The immediate social and physical landscape was so dominant it was impossible to write about anything else. It was presumptuous of me to comment so soon on a place that I knew little about, but I was writing from and on those dominant Australian institutions. To write critically about policies in education, economic development or constitutional change was in most cases to pass judgement on fellow Australians. The easy targets were those in high office who were blind to impending change, the planters who sat in exclusive clubs and railed against lazy and unreliable workers, and the Governor-General Sir Silas Atopare outlining the government's program for the next year. Three days later I made the short journey down Independence Drive from the Archives to the new national parliament and took a seat in the public gallery. The government faced significant issues: an agreement with the International Monetary Fund for emergency funding to rescue the economy had just been announced, half the K267 million contributions to the National Provident Fund were found missing, in the Eastern Highlands fighting in the Kofena and Kainantu areas had resulted in eighteen deaths and there were reports of high powered rifles being used, and the Loloata agreement had just been signed by central Government and Bougainvillean representatives. But my interest was in people as much as the topics causing debate.

When I began teaching at the Administrative College in 1966 the Australian government had recently accepted that it had to force the pace of Papua New Guinean advancement in the public service. The course in which I was teaching, 'Stage 2', was designed to take Papua New Guinean public servants and increase the standard of their general education to the level of fifth year in an Australian high school. It attracted some of the most able of the young Papua New Guineans then working for the government. At the same time I was assisting with the teaching of the fifty-eight students enrolled in the University of Papua New Guinea's first preliminary year. Gathered from the few students who had completed four years of secondary education in the Territory, or been to teachers college or Australian schools, six of the students were twenty-five or more, six were seventeen or less and four were women. In a country in which there had been almost no secondary education in government schools, the students reaching the Administrative College and the University in those early years were exceptional either by ability, chance or family background. As they graduated from the university from 1970 right when rapid localisation was 
taking place, many were soon in positions of power in the public service. Less predictable was the fact that nearly all chose to stand for election to parliament - even those who were heads of government departments.

As I listened to question time and the debates in Parliament I took particular notice of the Prime Minister, Sir Mekere Morauta, the ex-Prime Minister, Sir Rabbie Namaliu, and the Minister of Transport, Bart Philemon. All were from the first preliminary year of the University of Papua New Guinea. Dr John Waiko spoke, and he arrived in 1967 to join the second intake. Paul Pora, formerly Minister for Finance, was there, and he was in Stage 2 at the Administrative College in 1967, and later transferred to the University. There were others whom I had known as young men around the campus or Port Moresby, but who had not been in my courses. Later I lunched in the members' dining room with two ex-students and Ministers. In the lively conversation the frequent jokes came from reminiscences, many detailing misunderstandings and failings of naïve young teachers fresh from Australia. By the coincidence of finding a job in Port Moresby when the University was starting (a fact scarcely known to me) I had come to know some of the generation that would assume positions of power in Papua New Guinea. I had seen them grow from the tentative young men of nineteen who had knocked on my door in Waigani to explain that the bus had not come to take them to their breakfast to confident grey-haired men who direct the affairs of the nation. What they do was inconceivable to their grandparents, scarcely comprehensible to their parents, and astonishing to me - although I had gone along with all the glib statements made at official ceremonies about the opportunities and responsibilities that were soon to be theirs.

As a student of human behaviour, I am conscious of the privilege of having been able to observe those profound changes in lives. I appreciate the fact that the ex-students talk frankly with me and in front of me. And when I come to write about recent events in Papua New Guinea I use insights taken from watching and listening to them, but there are some things that I make oblique or leave out altogether. My advantage can be in generalisation, but not detail. Sentiment does not always lead to moderation. The brutal attack on a friend may result in an immediate desire for a tougher police response. Personal relationships need not lead to favouring one side over another. Ex-students oppose each other in parliament. In the civil war on Bougainville they were on both sides and in the middle. Ex-students have turned out to be rogues, likeable, but rogues. Thirty years of living in, visiting and thinking about a nation means accumulated sentiment attaching to people and places, and that has its impact on what can be known, what can be said, and what one wants to say.

At the first meeting of the Interim Council of the University of Papua New Guinea held in Port Moresby in October 1965 it was decided to start teaching in February 1966. As the University had neither teachers nor building this was a 
decision dependent on quick and temporary solutions, and it meant that there was little time to think about the content of courses. The history course had to be one familiar to teachers and with books readily available. Bill Gammage had just a few days in February 1966 to find stocks of text books in Sydney and get them consigned to Port Moresby. Bill had a course in modern European and overseas expansion underway by the time that I joined him at the showgrounds. The foundation professor of History, Ken Inglis, did not begin teaching until the start of the undergraduate courses in 1967, but during 1966 he was planning for the new courses. He had no doubt that the history of Papua New Guinea was going to be taught, it was just a matter of when and in what way.

At the Administrative College Peter Biskup, Cecil Abel and Brian Jinks were already teaching some Papua New Guinea history. Jinks was using Papua and New Guinea examples in his politics and government courses, Biskup and I had both written about Aboriginal history, and I was teaching the economic geography of Papua New Guinea using the World Bank Report as the class text. Much of Elton Brash's English was Another Country by black American novelist (called a 'Negro writer' on the dust jacket), James Baldwin. The visit by Tom Mboya, then Minister for Economic Planning and Development in Kenya, had stimulated interest in the history and current events in the new nations of Africa. For me, and I presume others, one compelling factor when thinking about the content of courses was daily being confronted by classes of Papua New Guineans (and one Samoan at the University), and it was in that context of trying to teach Papua New Guineans about Papua New Guinea and often settling for makeshift and parallel texts that Jinks asked Biskup and me to join him in writing a history of Papua and New Guinea suitable for high schools and the Administrative College students. We signed a contract in October 1966. Determined not to begin with European discovery, we were pleased with our first sentence, 'Man has been in New Guinea for a long time'. That sentence was soon to look both mundane and sexist.

The first Handbook of the University of Papua New Guinea was published in October 1966 and Inglis committed the new Department of History to teach the history of Papua New Guinea in the second semester of 1967. The only reference book listed was Charles Rowley's The New Guinea Villager. First published in 1965, it was subtitled A Retrospect from 1964. Significant as Rowley's book was, even more surprising in terms of its date of publication and its emphases was Stephen Reed's The Making of Modern New Guinea, with its concern for a 'Kanaka revolution', the emergence of a new society from the meeting of Europeans and New Guineans. But Reed's book had been published in 1943, it was out of print, and he could not, of course, foresee the impact of the war and the direction of post-war policies. Other anthropologists had written numerous monographs and several of them contained much history. Margaret Mead's New Lives for Old 
was a study of the war on Manus; Peter Lawrence's Road Belong Cargo not only followed cults through time, but included a rare, detailed biography of a New Guinean - Yali; and Richard Salisbury, who had written From Stone to Steel, was talking about his coming book which would give both a European and a village perspective on history. On a visit north in 1966, Inglis had brought with him a copy of K.M.Panikkar's Asia and Western Dominance. It was, Panikkar had claimed in 1953, the first time an Asia student had attempted to 'see and understand' 450 years of European activities in Europe. Panikkar was set as text for the first history undergraduate course to be taught at the University of Papua New Guinea.

As we prepared to teach Papua New Guinea history in the second semester of 1967, then, we were conscious of the way Asians were bringing Asian perspectives to their history, and that Africans were being put into African history; we had several books on white endeavours in Papua New Guinea (such as those by Souter, Mair and Legge); we had the lonely New Guinea Villager, and much other material that was fragmented, coming from several disciplines, and varying in its quality and purpose. The outside men in the government service, the missionaries, and Sir Hubert Murray had written extensively about what they did, and sometimes they were illuminating about those that they wished to govern or convert. Ken Inglis demonstrated what we might do in a lecture on the Russian traveller and scientist, Nikolai Miklouho-Maclay, who had first landed on the Madang Coast (he left his name on the Rai Coast) in the 1870s. In the writings then available Inglis had sufficient information available to name individual New Guineans who had met Maclay and say something of their immediate and long term-responses to his visit. That set a pattern of not trying to present a Papua New Guinean perspective or a history of Papua New Guineans, but of giving two sides. This also worked effectively where we were dealing with topics other than those that were obviously meetings. For example, it was simple enough for us to look up the labour regulations governing plantation workers and talk about hours of work, rates of pay, ration scales, rules governing recruiting, and changes over time. The Territory's Annual Reports provided generalised information on the numbers of recruits, which districts they came from, which industries they worked in, and how long they signed-on for: but in tutorials there were students who had lived alongside plantations and those whose fathers had worked on them. Similarly when teaching about the Second World War, missions, village officials, and patrol officers, the history staff could present the official policy, the legal framework, how the literate claimed they behaved, say something about what was said about Papua New Guineans in the written record, obtain limited testimony from those involved, and then invite discussion in tutorials. Many of those tutorials were rich occasions for me, and I hope of some interest to those Papua New Guineans and Australians who were there as students. 
Later when I was writing about Papua New Guineans - such as Papuan medical assistants and those who served in the Pacific Islands Regiment - I was continuing what had seemed effective in teaching. I was certainly concerned about the experience of Papua New Guineans and I talked to them, but the articles were saying at least as much about policies and prejudices of Australians who managed and commented on Papua New Guineans employed in Australiandominated institutions. The book on gold mining, Black, White and Gold, was more obviously about meetings; for each goldfield had a very different history: white miners with the same inclinations and presumptions simply behaved differently on Misima to what they did on the Yodda or Keveri or the Lakekamu. Bill Gammage, who had not learnt the approach from me because he and others were already talking and writing in a similar way, made this form of history richer in detail and more elegant in presentation in his article on the Rabaul strike and in his recent book The Sky Travellers.

In the early years when we began teaching the history of Papua New Guinea, I would have written about Papua New Guineans, trying to see experiences from their point of view, paraphrasing what they thought about what had happened to them, and assessing the impact on Papua New Guinean communities. But by the time I may have known enough to attempt to do that, circumstances and attitudes had changed, and I was saved from presumption. Australia was handing powers to Papua New Guineans and they were rapidly taking control of institutions - from parliament to the post office - and making them their own. It was reasonable to think that they were about to shift behind the desks once occupied by foreign historians, re-read old sources, exploit new ones, and write their histories. Also, where in 1966 we had been on the end of the movement that was putting Asians and Africans into their own history, by the time Papua New Guinea was becoming independent, various people around the world were saying that they owned their own past and they resented outsiders telling them who they had been, what had happened to them, and why they were who they were. That movement to claim group histories was probably strongest among minorities crowded out of national histories by those who were more numerous and had greater access to power, education and the media. Aborigines, AfroAmericans, Hawaiians, Maoris and Native Americans have all suffered exclusion and made strong claims for both recognition in the national history and for a another history - one that was different from that of the dominant groups. Those arguments were put less frequently and less stridently by Papua New Guineans, who had retained languages and land, were numerically dominant, and now had their own nation. For peoples who possessed the present, history was not as important as it was for those who felt dispossessed of both past and present. The few Papua New Guineans wanting to lay claim to the past 
by argument or by putting forward an alternative view, did little to diminish the inhibitions felt by foreigners who may have wanted to present Papua New Guineans with their own history.

The restraints on writing about current events - sentiment, the sense of being an outsider, personal considerations - were paralleled by the factors that help persuade historians to choose one topic over another. In 2000, based in Canberra, I like to take a perspective from somewhere in the Coral Sea, looking north and south, explaining Papua New Guineans to Australians, Australians to Papua New Guineans, Australians to Australians, but not completing the reflections by trying to tell Papua New Guineans about Papua New Guineans. The young Papuan woman at Jacksons International Airport had indeed asked a complex question, 'Have you been to our country before?' I had, but it had been different then, and it has been different on every arrival since. This time I even got confused trying to drive across Gordons to the university. The new Poreporena Freeway blocked my way; but then visiting historians are likely to find the signs hard to read. 
This text taken from The Boy from Boort: Remembering Hank Nelson, Edited by Bill Gammage, Brij V. Lal, Gavan Daws, published 2014 by ANU Press, The Australian National University, Canberra, Australia. 